\title{
Jurnal

\section{EFFEKTIFITAS YOGA STICK TERHADAP PENGURANGAN NYERI PUNGGUNG DAN LEHER PADA ORANG DEWASA}

\section{The Effectiveness of Yoga Stick on The Reduction of Back and Neck Pain in Adults}

\author{
Iis Noventi, Nur Ainiyah
}

Universitas Nahdlatul Ulama Surabaya

\section{Riwayat artikel}

Diajukan: 9 Februari 2021

Diterima: 20 Februari 2021

\section{Penulis Korespondensi:}

- Iis Noventi

- Lecture

- Universitas Nahdatul Ulama Surabaya

e-mail:

iisnoventi@unusa.ac.id

\section{Kata Kunci:}

Yoga Stick, Nyeri punggung, leher, orang dewasa

\begin{abstract}
Abstrak
Pendahuluan : Nyeri punggung adalah nyeri, kekakuan dan perasaan tidak nyaman yang dirasakan oleh seseorang di sepanjang tulang belakang dari dasar leher hingga ke tulang ekor. Nyeri punggung dan leher banyak terjadi pada usia produktif, lansia bahkan anak - anak. Setidaknya nyeri punggung hampir dialami banyak orang, minimal sekali dalam hidupnya. Stick Yoga adalah teknik peregangan dengan menggunakan tongkat dengan panjang kurang lebih 4 kaki atau 6 kaki untuk pengungkitan, dukungan, dan keseimbangan. Tujuan: Untuk mengetahui effektifitas Yoga Stick terhadap pengurangan nyeri punggung dan leher pada orang dewasa. Metode: penelitian ini menggunakan jenis quasy eksperiment dengan rancangan penelitian pre test post test Non - equivalen control group. Penilaian nyeri punggung dan leher menggunakan BackPEI (Posture Evaluation Instrument) versi Noll (2012). Hasil: nyeri punggung bawah sebelum dan setelah perlakuan yoga stick menggunakan uji statistic Paired Samples Test yang menunujukkan penurunan nyeri punggung dan leher di buktikan dengan nilai $p$ value 0,000. Kesimpulan: Latihan Yoga Stick secara teratur dapat mengurangi nyeri punggung dan meningkatkan kualitas hidup seseorang.
\end{abstract}

Abstract
Background: Back pain is pain, stiffness and discomfort felt by a person along the spine from the base of the neck to the coccyx. Back and neck pain occurs a lot at productive age, the elderly and even children. At least back pain is experienced by many people, at least once in their life. Stick Yoga is a stretching technique using a stick approximately 4 feet or 6 feet long for leverage, support, and balance. Objective: To determine the effectiveness of the Yoga Stick in reducing back and neck pain in adults. Method: The study used a quasy type of experiment with a pre-test post- test research design of non-equivalent control group. Assessment of back and neck pain uses Noll's version of BackPEI (Posture Evaluation Instrument) (2012). Results: low back pain before and after yoga stick treatment used the Paired Samples Test statistical test which showed a reduction in back and neck pain as evidenced by a p value of 0.000 Conclusion: Regular Yoga Stick practice can reduce back pain and improve person,s quality of life. 


\section{PENDAHULUAN}

Nyeri punggung adalah nyeri yang dirasakan oleh seseorang mulai dari pangkal leher sampai dengan pinggul. keluhan ini disebabkan karena beberapa faktor antara laian cidera, aktifitas fisik, atau kondisi medis tertentu. sakit punggung bawah bisa akut atau kronis, nyeri pungung bawah akut didefinisikan sebagai nyeri lumbosakral yang berlangsung kurang dari enam minggu dengan atau tanpa gejala yang progressif atau melumpuhkan. nyeri punggung paling akut bersifat mekanis, sebagai akibat dari trauma pada punggung bawah atau kelainan seperti artritis. Gaya hidup yang monoton sudah menjadi tren pada masyarakat modern saat ini. Transisi gaya hidup demikian menyebabkan perubahan pada tingkat aktifitas yang cenderung malas untuk bergerak, semua kebutuhan sudah tersedia tanpa harus bersusah payah dan kebiasaan tidak menjadikan postur tubuh dengan baik. Salah satu keluhan yang paling banyak dikeluhkan adalah nyeri punggung dan leher. Keluhan ini sangat mempengaruhi kualitas hidup seseorang, usaha pencegahan dapat dilakukan untuk mengurangi keluhan tersebut. Namun tindakan pengurangan rasa nyeri masih banyak yang di biarkan tanpa tindakan apapun atau juga sudah melakukan exercise tapi belum memberikan dampak yang maksimal.

Nyeri punggung bawah adalah salah satu alasan paling umum untuk kunjungan rawat jalan dan $80 \%$ hingga $90 \%$ populasi akan mengalami masalah ini pada suatu waktu (Roudsari, 2010). Sekitar 20\% pasien dengan nyeri punggung bawah akut akan berlanjut mengalami gejala kronis (Sawyer A., Martinez, 2012). Selain menyebabkan ketidaknyamanan umum, nyeri punggung bawah kronis dapat mengganggu aktivitas hidup sehari-hari dengan mengurangi mobilitas, menghambat tugas kerja, dan berdampak negatif pada perawatan diri (Devi M, Sulaiman, dkk, 2014). Defisit fungsional ini dapat memiliki konsekuensipsikologis dan emosional yang merugikan juga (Meliala A., 2003 ). Di Indonesia diperkirakan angka prevalensi $7,6 \%$ sampai $37 \%$. Masalah nyeri punggung pada pekerja pada umumnya dimulai pada usia dewasa muda dengan puncak prevalensi pada kelompok usia 25-60 (Steven, 2005 ). Menurut Purwata, et al., nyeri punggung bawah adalah Inyeri neuropatik yang paling sering ditemukan di Indonesia.

Menurut penelitian Meucci $\mathrm{R}$, et al., angka prevalensi nyeri punggung bawah tiga hingga empat kali lipat lebih tinggi di atas usia 50 tahun dibandingkan dengan di antara usia 18 hingga 30 tahun. Nyeri punggung bawah kronis adalah $4.2 \%$ di antara usia 24 - 39 tahun dan $19.6 \%$ diantara 20-59 tahun. Instrumen Evaluasi Back Pain dan Postur Tubuh (BackPEI) adalah kuesioner untuk menilai adanya nyeri punggung dan faktor risiko terkait. Penilaian nyeri punggung dan leher menggunakan BackPEI ( Posture Evaluation Instrument) versi Noll (2012) yang terdiri dari beberapa pertanyaan tentang posisi duduk saat menulis/membaca, posisi duduk menemui tamu/istirahat, posisi duduk saat menonton televisi/ melihat handphone, posisi saat mengambil benda dari lantai, pernah terlibatdalam kecelakaan mobil dan motor, kebiasaan berolah raga, kebiasaan membaca/belajar sambil tidur, posisi tidur, lamanya tidur, keluhan nyeri punggung dalam waktu 3 bulan terakhir, dan yang menghambat aktifitas sehari-hari.

Yoga adalah merupakan salah satu terapi komplementer yang lebih mengarah pada gerakan tubuh yang mencakup postur fisik (asana), latihan pernapasan (pranayama), dan meditasi. Yoga berasal dari India yang merupakan salah satu cara pemujaan kepada Semesta, seiring dengan perkembangan waktu Yoga berkembang menjadi terapi non farmakologis dengan cara menggerakkan tubuh yang bersinergi dengan pikiran sehingga tercipta sebuah ketengan hati yang mempengaruhi tubuh dan pikiran. Stick Yoga adalah teknik peregangan dengan menggunakan tongkat atau tongkat dengan panjang kurang lebih 4 kaki atau 6 kaki untuk pengungkitan, dukungan, dan keseimbangan yang idealnya dengan musik di alam, bersenang-senang, dan meningkatkan kepercayaan diri. Penelitian terbaru menunjukkan bahwa yoga dapat meringankan sakit punggung dan mengurangi kecacatan fungsional yang terkait dengan sakit punggung ([Sawyer A., Martinez and Gordon.,L.,Warren.,2012).

\section{METODE}

Penelitian ini merupakan penelitianquasy eksperiment. Dengan rancangan penelitian pre

(Noventi, et al, 2021) 
test post test Non - Equivalent control group. Pengambilan sampel pada penelitian ini menggunakan teknik non probability sampling jenis purposive sampling, dengan jumlah sampel 20 orang dewasa yang mengeluhkan nyeri punggung dan leher dalam 3 bulan terakhir di komunitas Yoga Asma di Surabaya. Penilaian nyeri punggung dan nyeri leher menggunakan Back Posture Evaluation Instrument (BackPEI) versi Noll (2012) yang terdiri dari beberapa pertanyaan tentang posisi duduk saat menulis/membaca, posisi duduk menemui tamu/istirahat, posisi duduk saat menonton televisi/ melihat handphone, posisi saat mengambil benda dari lantai, pernah terlibat dalam kecelakaan mobil dan motor, kebiasaan berolah raga, kebiasaan membaca/belajar sambil tidur, posisi tidur, lamanya tidur, keluhan nyeri punggung dalam waktu 3 bulan terakhir, dan yang menghambat aktifitas sehari-hari. tingkatan nyerinya menggunakan alat ukur VAS (Visual Analog Scale). Subjek dalam penelitian ini adalah orang dewasa yang mempunyai keluhan nyeri punggung dan nyeri leher dalam waktu 3 bulan terakhir. Kriteria inklusi usia 30 - 50 tahun, mempunyai keluhan nyeri punggung dan leher.

\section{Tehnik Analisis Data}

Analisa Data adalah :

Untuk mengetahui efektifitas yoga stick terhadap nyeri punggung ( sebelum dan sesudah yoga stick ) uji statistiknya dengan uji $T$ Test dengan tingkat kemaknaan $<0,05$, dilakukan uji statistik dengan menggunakan program SPSS.

\section{HASIL DAN PEMBAHASAN HASIL}

Hasil analisa pada penelitian iniadalah sebagai berikut:

Karakteristik responden berdasarkan Usia,Jenis Pekerjaan

Tabel 1 Distribusi frekuensi karakteristik responden berdasarkan usia, pekerjaan

\begin{tabular}{lll}
\hline variabel & N responden & \% \\
\hline Usia & & \\
\hline $30-35$ tahun & 8 & 40 \\
\hline $36-40$ tahun & 7 & 35 \\
\hline $41-50$ tahun & 5 & 25 \\
\hline Pekerjaan & & \\
\hline Bekerja & 9 & 45 \\
\hline Tidak Bekerja & 11 & 55 \\
\hline
\end{tabular}

Tabel 1 menunjukkan bahwa mayoritasresponden dalam penelitian adalah umur 30-35 tahun yaitu sebanyak 8 responden (40\%). Berdasarkan status pekerjan responden dalam penelitian bahwa mayoritas responden tidak bekerja sebanyak 11 responden (55).

Tabel 2. Distribusi frekuensi tingkat nyeri punggung bawah da leher berdasarkan level sebelum dan setelah yoga stick

\begin{tabular}{|c|c|c|c|c|}
\hline \multicolumn{2}{|l|}{ Kategorik } & \multirow{3}{*}{$\begin{array}{c}\begin{array}{c}\text { Pre } \\
\text { Test }\end{array} \\
\% \\
0\end{array}$} & \multicolumn{2}{|r|}{ Post Test } \\
\hline r & 1 & & $\mathrm{n}$ & $\%$ \\
\hline Tidak Nyeri & & & 10 & 50 \\
\hline Ringan & 5 & 25 & 8 & 40 \\
\hline Sedang & 14 & 70 & 2 & 10 \\
\hline Hebat & 1 & 5 & 0 & 0 \\
\hline Berat & 0 & 0 & 0 & 0 \\
\hline $\begin{array}{l}\text { Mean } \pm \text { SD } \\
41,9 \pm 19,06\end{array}$ & & & & $4 \pm 15,52$ \\
\hline p-value & 0,000 & & & \\
\hline
\end{tabular}

Dari tabel 2 dapat diketahui bahwa sebelum dilakukan latihan yoga stick sebagian besar responden mengalami nyeri sedang yaitu sebanyak 14 responden $(70 \%)$, yang mengalami nyeri punggung ringan sebanyak 5 responden $(25 \%)$ sedangkan yang mengalami nyeri punggung hebat sebanyak 1 responden (5\%). Setelah melakukan latihan yoga stick secara teratur terjadi perubahan pada ambang nyeri dengan menggunakan pengukuran VAS hal ini bisa dilihat dari hasil sebagian besar responden mengalami nyeri dalam tingkat ringan yaitu sebanyak 8 responden (40\%), nyeri sedang 2 responden (10\%) dan 10 responden $(50 \%)$ sudah tidak mengeluhkan nyeri punggung seperti sebelumnya. Jika dilihat dari rerata nyeri punggung bawah sebelum perlakuan $41,9 \pm 19,06$, rerata setelah perlakuan $16,4 \pm 15,52$ dan selisih rerata antara tingkat nyeri sebelum dan setelah

(Noventi, et al, 2021) 
perlakuan adalah 25,5. Hasil analisis nyeri punggung bawah sebelum dan setelah perlakuan yoga stick menggunakan Paired Samples $T$ Test diperoleh nilai $p$ value 0,000 artinya ada penurunan nyeri punggung bawah dan leher setelah perlakuan yoga stick sehingga ada efektifitas yang signifikan yoga stick terhadap nyeri punggung bawah dan leher sebelum dan setelah perlakuan.

\section{PEMBAHASAN}

Temuan utama dari penelitian ini menunjukkan bahwa latihan yoga stick dapat mengurangi rasa sakit dan meningkatkan kemampuan fungsional pada peserta yoga dengan nyeri punggung kronis. Mengingat temuan ini, yoga mungkin dianggap sebagai pengobatan yang efektif untuk individu dengan nyeri punggung bawah kronis yang mencari intervensi non-bedah. Selain meregangkan dan memperkuat otot-otot punggung dan ekstremitas bawah melalui postur fisik, yoga mungkin memiliki manfaat tambahan untuk mengurangi stres melalui meditasi dan latihan pernapasan, berkontribusi pada pengurangan keseluruhan gejala untukindividu dengan nyeri punggung.

Intervensi yoga stick diajarkan lebih beragam asananya dan stick atau tongkat menjadi alat bantu untuk memperbaiki tubuh terutama pada punggung yang nyeri. Yoga Stick dapat memengaruhi pesertamelalui cara fisik dan mental, dan penelitian saat ini tidak menunjukkan bagaimana hal ini dapat terjalin untuk memengaruhi nyeri punggung bawah. dimana yoga stick mengurangi rasa sakit dan meningkatkan fungsi.

Yoga merupakan salah satu terapi komplementer yang mempunyai manfaat salah satunya adalah mengurangi rasa nyeri (Sindhu, 2009). Yoga mmpunyai manfaat untuk mengurangi strss melalui meditasi dan latihan pernafsan yang berkontribusi dalam peregangan yang bisa mengurangi rasa nyeri. Selain itu yoga stick untuk mempaiki postur lebih tegap, serta melenturkan otot dan membuat tubuh lebih kuat. Dengan melakukan yoga stick secara teratur otot otot punggung akan lebih lentur, sirkulasi darah lebih lancar dan meningkatkan kewaspadaan seseorang lebih tajam terhadap stimulasi. gerakan yoga stick yang lebih banyak menggunakan otototot punggung, bahu dan leher akan merangsang otot-otot pada punggung dan memperpanjang otot punggung sehingga dapat memblokade timbulnya rangsangan nyeri terutama dibagian punggung. Aliran darah yang lancar dapat merangsang otak untuk mengeluarkan obat anti nyeri secara fisiologis sehingga seseorang lebih rilek dan nyaman.

\section{KESIMPULAN}

Dari penelitian ini dapat disimpulkan bahwa nyeri punggung dan leher dapat dikendalikan dengan latihan yang terartur. Latihan seperti Yoga Stick adalah intervensi lain yang dapat mengurangi rasa sakit dan meningkatkan kualitas hidup seseorang dengan meningkatkan kemampuan fungsional pada seseorang dengan nyeri punggung bawah kronis. Latihan ini membantu meregangkan dan memperkuat otot-otot punggung dan ekstremitas bawah melalui postur fisik, yoga mungkin memiliki manfaat tambahan untuk mengurangi stres melalui meditasi dan latihan pernapasan, berkontribusi pada pengurangan keseluruhan gejala untuk individu dengan nyeri punggung. Dengan demikian, latihan tersebut adalah strategi yang lebih baik untuk mengelola kebugaran tubuh dan dapat dipraktikkan secara teratur, ini adalah alternatif pendekatan nonfarmakologis dan membantu individu untuk mengatasi nyeri punggug dan leherpada tahap awal yang mempromosikan perawatan komplementer.

\section{DAFTAR PUSTAKA}

Allison, 2018. Stick yoga. http://drdeliman.com/tag/balance/ diakses tgl 3 februari 2020

Bal, B.S.;Kaur,P.J. 2009. Effects of Selected Asanas in Hatha Yoga on Agility and Flexibility level. J Sport Health Res, 1(2):75-87 
Devi M, Sulaiman, Rosnani, Jawiah.Pengaruh Yoga Antenatal Terhadap Pengurangan Keluhan Ibu Hamil Trimester

III. Jurnal kedokteran dan kesehatan, volume 1, no. 1, Oktober 2014;47-53

Meliala A., 2003, Nyeri Punggung Bawah, Dalam: Assesmen NPB, Perdossi, pp : 37 - 49.

Meliala L,Pinzon R, Patofisiologi dan Penatalaksanaan nyeri punggung bawah, Dalam: Meliala L, Rusdi I, Gofir A, editor. Pain Symposium: Towards Mechanism Based Treatment, Jogjakarta, Hal. 109-116. 2004.

Meliawan S., 2009. Diagnosis dan Tatalaksana HNP Lumbal. Dalam : Diagnosis dan Tatalaksana Kegawat Daruratan Tulang Belakang. Jakarta. Sagung Seto. p; 62-87

Maher JP, Doerksen,SE, Elaysky,S et al. 2013. A Daily Analysis of Physical Activity and Satisfaction With Life in Emerging Adults. Health Psychol. 2013 Jun;32(6):647- 56. doi: 10.1037/a0030129. Epub 2012 Oct

22.

Noll.,M,Tarrago.,C.,Vieira.,A.,Loss.,J.2012

- Back Pain and Body Posture Evaluation Instrument ( BackPEI): Development, Content validation and Reproducibility. Int J Public Health. 2013 Aug;58(4):565-72. doi: 10.1007/s00038-012-0434-1. Epub 2012 Dec 30.

Roudsari B, Jarvik JG. Lumbar spine MRI for low back pain: indications and yield. $A J R$ Am J Roentgenol. 2010;195(3):550-59.

Sindhu, P. (2007). Hidup Sehat dan Seimbangdengan Yoga. Bandung: Qanita

Sawyer A., Martinez and Gordon.,L.,Warren., 2012. Impact of
Yoga on Low Back Pain and Function: A Systematic Review and meta Analysis. J Yoga Phys Ther Vol. 2 (4)2012 ISSN:2157-7595

The consensus document. The Bone and Joint Decade 2000-2010. Inaugural Meeting 17 and 18 April 1998, Lund, Sweden. Acta Orthop Scand 1998;69 (suppl 281):67-86 